\title{
Researches on the mixture limits of animal fats with liquid hydrocarbons for combustion at industrial level
}

\author{
Dana Andreya Bondrea ${ }^{*}$, Lucian Mihaescu ${ }^{2}$, Gheorghe Lazaroiu ${ }^{3}$, Ionel Pisa ${ }^{4}$ and Gabriel \\ Negreanu ${ }^{5}$ \\ ${ }^{1}$ University POLITEHNICA of Bucharest, Department of Hydraulics, Hydraulic Machinery and Environmental Engineering, \\ Romania \\ ${ }^{2,4,5}$ University POLITEHNICA of Bucharest, Romania Department of Thermotechnics, Engines, Thermal and Frigorific Equipment \\ ${ }^{3}$ University POLITEHNICA of Bucharest, Department of Energy Production and Use
}

\begin{abstract}
The experimental research has highlighted the variety of possibilities of combustion of animal fat from bovine and swine mixed with liquid hydrocarbons. Previous research has established that the upper limit for an efficient combustion was $30 \%$. For a perfect mixing, the lower temperature limit was set to $40{ }^{\circ} \mathrm{C}$. In the fuel laboratory, at the department TMETF was determined the viscosity of the mixtures for different proportions. The values obtained for various concentrations and preheating temperatures were close to the values for liquid hydrocarbons. The experimental researches have studied the combustion of the mixture using a mechanically spraying burner with constant pressure between 14 and 18 bar. The aspiration of the mixture is done from a specially designed tank; this tank is equipped with an electric heater, in order to maintain the mixture at a constant temperature between $40{ }^{\circ} \mathrm{C}$ to $50{ }^{\circ} \mathrm{C}$. After that, the burner heats again the mixture with an integrated heating device up to $75^{\circ} \mathrm{C}$. The burner is also equipped with an air blower, pump and a calibrated nozzle. The combustion resulted from the experimental boiler with a power rated to $55 \mathrm{~kW}$ were monitored with a thermal vision camera and an exhaust gas analyser. This research has demonstrated the viability of using this type of mixtures in energetic burning equipment designed for liquid hydrocarbons.
\end{abstract}

\section{Introduction}

The method of combustion of animal fats (especially for bovine) was developed as a requirement for leather industry, because the animal fats are a waste which is hard to neutralize. As a result, the combustion of these animal fats is a solution which has energy and ecologically impact. The amount of animal fat waste in the leather industry is not very high, so it is planned to produce thermal energy through combustion in the boiler's furnace [1-3]

The combustion research on a diesel engine is not part of this paper. In the current state of development, the leather industry produces annually 11.000 to 12.000 tons of waste for combustion neutralization, representing about $50 \%$ animal fats and $50 \%$ protein. If protein is studied in order to transform it into biogas through anabolism, the animal fats can be burned by mixing in liquid hydrocarbons. The method of burning animal fats in liquid hydrocarbons is the main subject of this paper [4-7].

Previous studies on the physical, chemical and energetic characteristics of animal fats have indicated:

- Elemental analysis;

- $\quad$ The melting temperature in the liquid phase, minimum $40^{\circ} \mathrm{C}$.

Preliminary research has demonstrated the possibility of combustion for the $30 \%$ concentration of animal fats in liquid hydrocarbons. For spraying and combustion studies it was necessary to determine the viscosity of the previously defined mixtures [8-11]. 


\section{Determination of viscosity of the mixtures composed from animal fats and liquid hydrocarbons}

The determinations were made in the University Politehnica of Bucharest, The Faculty of Mechanical Engineering and Mechatronics, department Thermal Systems and Equipment, Hydraulic and Pneumatic Systems and Equipment. In figure 1 are presented the experimental stand with:

1. Process control thermometers;

2. Viscometer Engler;

3. System with electric heating stovetop for samples;

4. Balance for weighing the mixture;

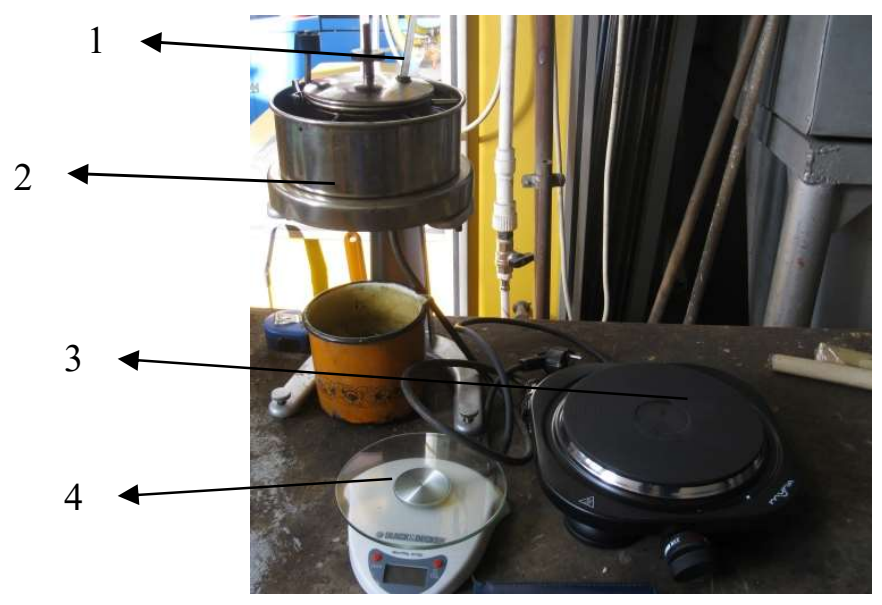

Fig.1. The equipment used to determine viscosity for animal fat mixed in liquid hydrocarbons

The experiments were done with fat from bovine and swine. The bovines and goats are a more important source for leather industry than swine. Figures 2 and 3 show the variation of the viscosity of the mixed liquid fuels with different animal fat concentration $(10 \%, 20 \%$ and $30 \%)$ depending on the temperature.

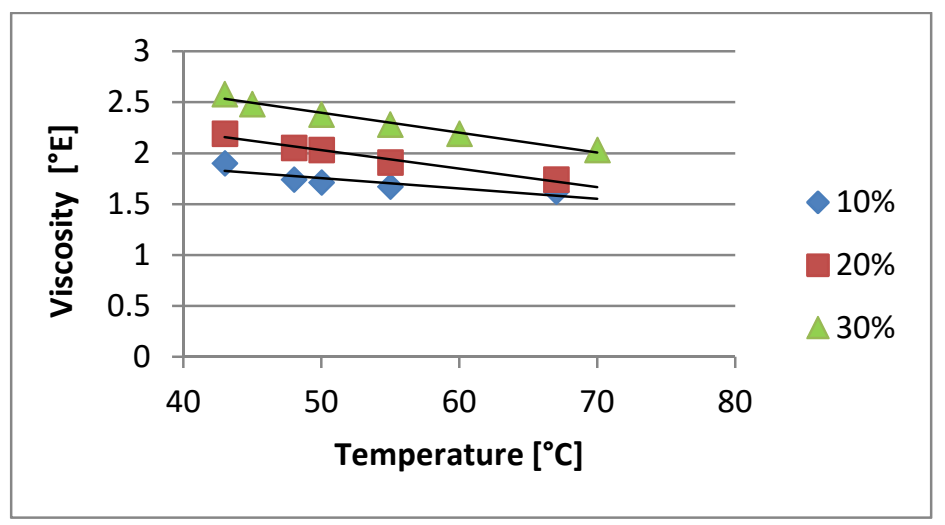

Fig.2. The viscosity variation of the mixture animal fats from bovine with liquid hydrocarbons

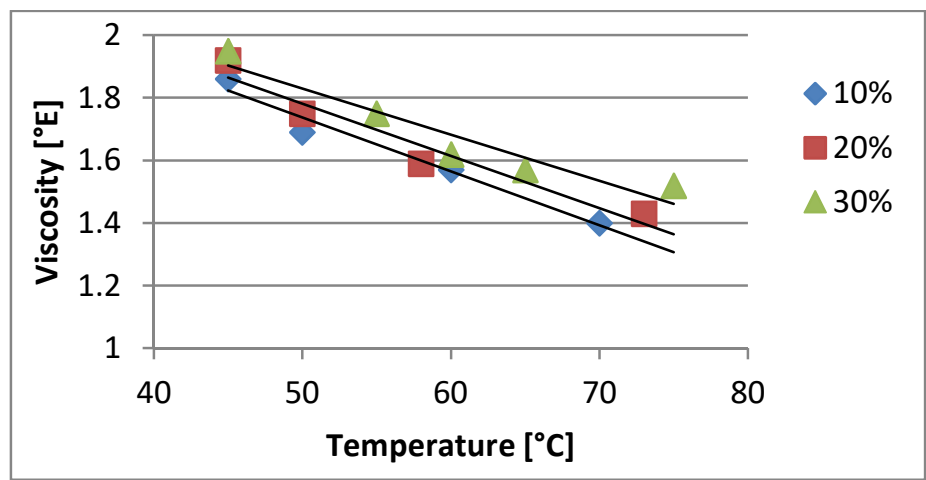

Fig.3. The viscosity variation of the mixture animal fats from swine with liquid hydrocarbons 
In figure 4 and figure 5 are show the variation of the density of the mixture analysed.

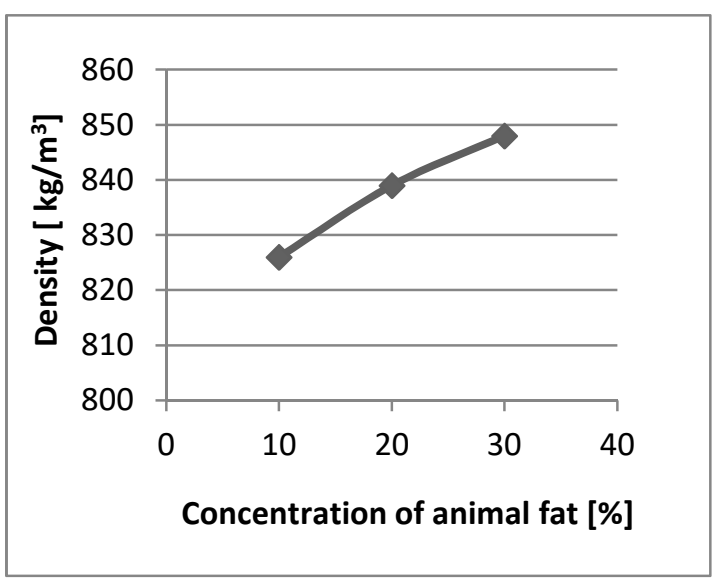

Fig.4. The variation of the density of the mixture of animal fats from bovine with liquid hydrocarbons

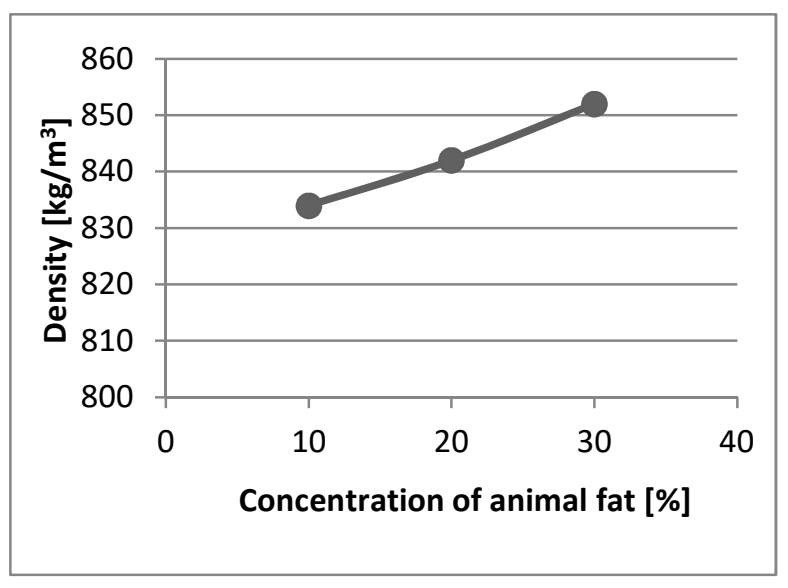

Fig.5. The variation of the density of the mixture of animal fats from swine with liquid hydrocarbons

For the viscosity and density characteristic, the experimental determinations have demonstrated a very large approximation for mixture with pure liquid hydrocarbons, thus confirming the results of an efficient combustion with non-modified burners for liquid hydrocarbons.

\section{The results of experimental and simulation tests of combustion of mixture}

The combustion tests occurred in a hot water boiler, the boiler has a power rated to $55 \mathrm{~kW}$ and it is equipped with a burner GB - Ganz type ANYO -12R-2-1-0. The burner is designed for burning liquid hydrocarbons. The experimental results confirm the successful use of these mixtures to small and medium sized hot water boilers. These boilers can be used to heat the space of production units in the leather industry or for industrial hot water generation [12-14].

In figure 6 can be seen the boiler installation together with a specially designed tank for the preparation of mixtures equipped with an electric heater located outside the burner.

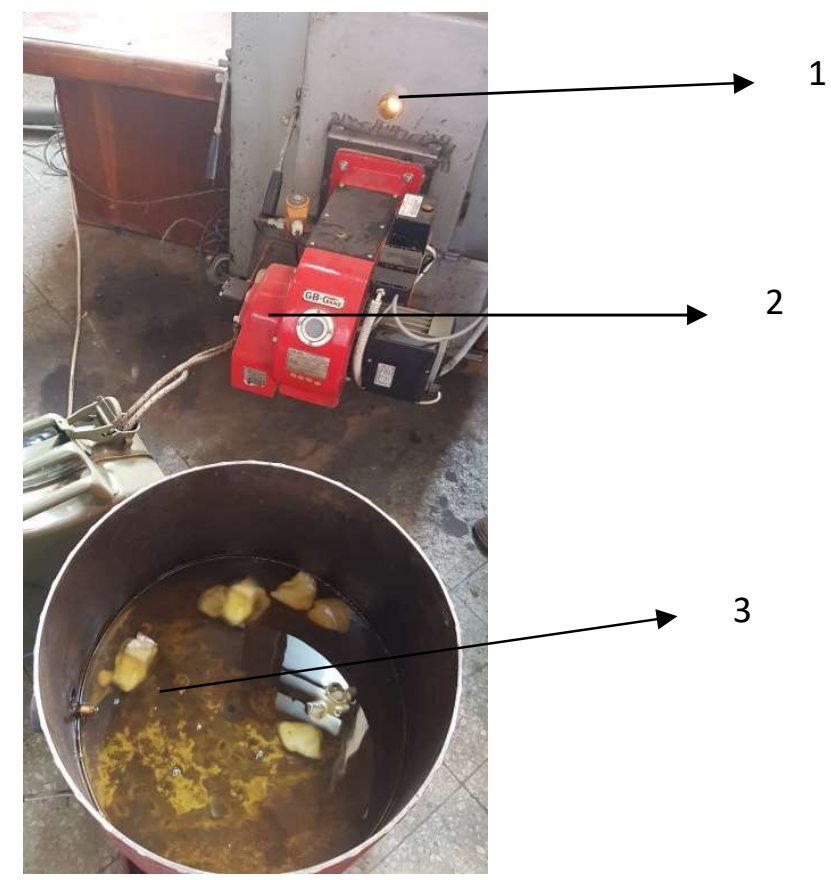

Fig.6. The experimental installation: 1) the boiler 2) the burner and 3) the specially tank 
In order to achieve and control mixtures, it was used a free volume tank presented in figure 6 , number 3 . The tank is equipped with an electric heater and a contact thermocouple. The mixture is made in this tank with various concentrations by heating at temperatures between $40{ }^{\circ} \mathrm{C}$ to $50{ }^{\circ} \mathrm{C}$; at these temperatures the animal fat is completely dissolved in liquid hydrocarbons ( in this case: diesel oil). The maximum temperature of $50{ }^{\circ} \mathrm{C}$ is required by the operation of the burner pump on the suction side [15].

- The burner has a mechanical spray pump with constant pressure between 14 bar to 18 bar, the spray quality is also achieved with an integrated heating device at $70^{\circ} \mathrm{C}$ to $75^{\circ} \mathrm{C}$. The burner has a flame stabilizer mounted on the air outlet section, which generates a local swirl. The swirling is achieved through channels with $60^{\circ}$ inclined air outlet. The first part of the flame develops into a circular channel with a $74 \mathrm{~mm}$ inner diameter, which fixes the tangential component, so that the flame will be narrow. The construction of the burner in the aerodynamic part of the flame is presented in the figure 7 [16].

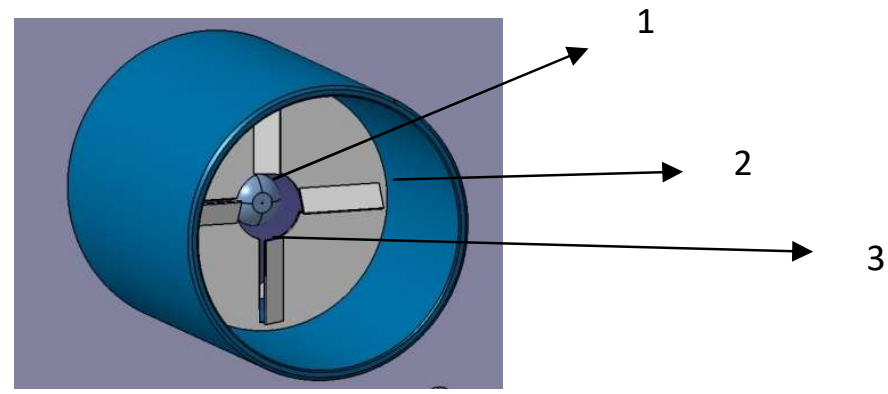

Fig.7. The construction details of the burner 1) spray nozzle 2) circular flame flow channel 3) tangential slits

The analytical calculation highlighted the next functional elements for the burner:

- Axial air velocity in the exit section: $\mathrm{u}_{\mathrm{x}}=20 \mathrm{~m} / \mathrm{s}$;

- The tangential velocity: $u_{\varphi}=37 \mathrm{~m} / \mathrm{s}$;

- The equivalent degree of swirl: $n=27$;

- The mass of fluid, $\mathrm{m}$, entrained by the jet with the initial mass $\mathrm{m}_{0}$, at a distance, $\mathrm{x}$, from the diameter, $\mathrm{D}$ :

$$
m=m_{0}(0.32+0.4 n) \frac{x}{D}
$$

- The average fuel particle diameter for the 18 bar pressure and animal fat concentration $30 \%: \mathrm{d}=23 \mu \mathrm{m}$

- The combustion time calculated according to Spalding model: $\tau=0.23 \mathrm{~s}$

- $\quad$ The length of the flame, L, calculated with the relation below, has a value confirmed by the figure 8:

$$
L=u_{x} \cdot \tau=20 \cdot 0.23=0.46 m
$$

In figure 8 is showed the aspect of the flame for the mixture with a concentration of $30 \%$ bovine animal fat in liquid hydrocarbons. The measured flame was $0.468 \mathrm{~m}$, this value confirming the calculations of the analytical models.

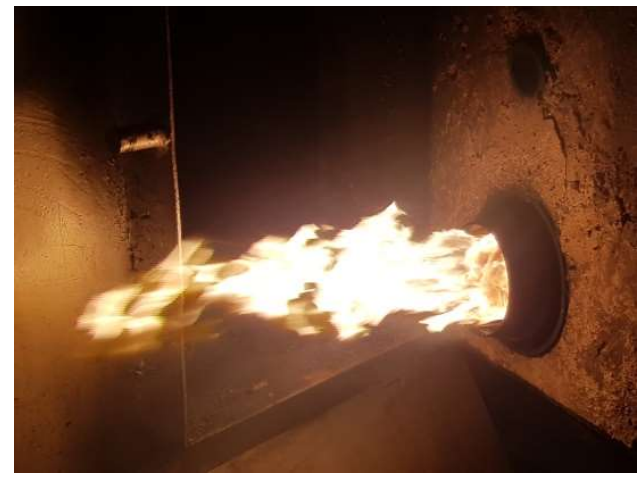

Fig.8. The aspect of the flame for $30 \%$ mixture bovine animal fat

For a complete characterisation of the combustion processes, a numerical modelling of the processes by using the program ANSYS WORKBENCH 14.0 CFX was performed. The simulation of the flame was done in $2 \mathrm{D}$. Aerodynamics of the flame jet regarding the velocity range from exit of the spray nozzle to the end of the boiler is shown in figure 9. 


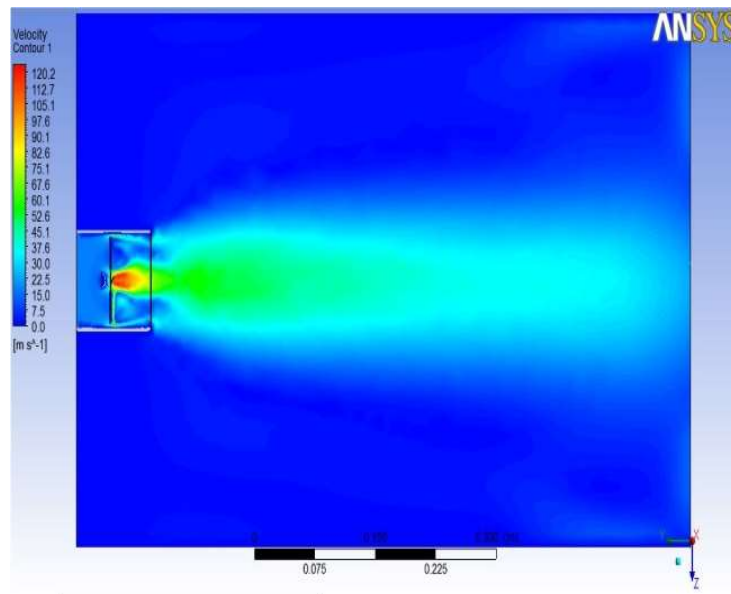

a)

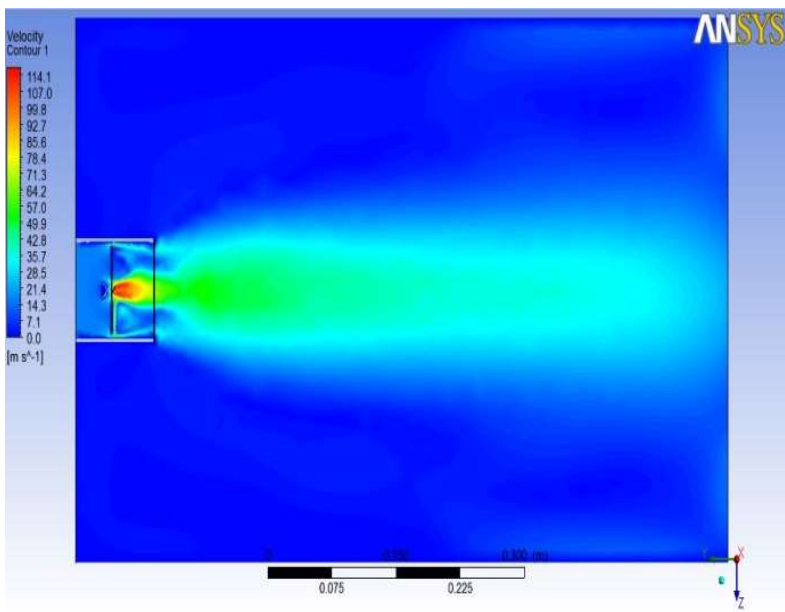

b)

Fig.9. The flame speed range a) for the mixture with a $30 \%$ concentration of bovine animal fat; $b$ ) for the mixture with a $30 \%$ concentration of swine animal fat

The aspect of the flame respects the results of the analytical study, the flame being long and thin. However, when using swine animal fat, the flame is $10 \%$ thicker.

The heat range, defined by the flame temperatures, indicates for both mixtures, a core peak in the first flame combustion.

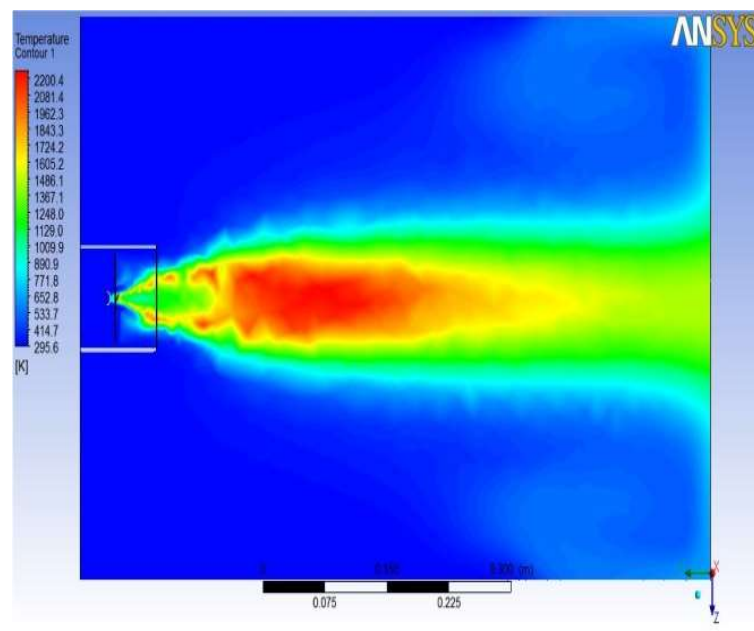

a)

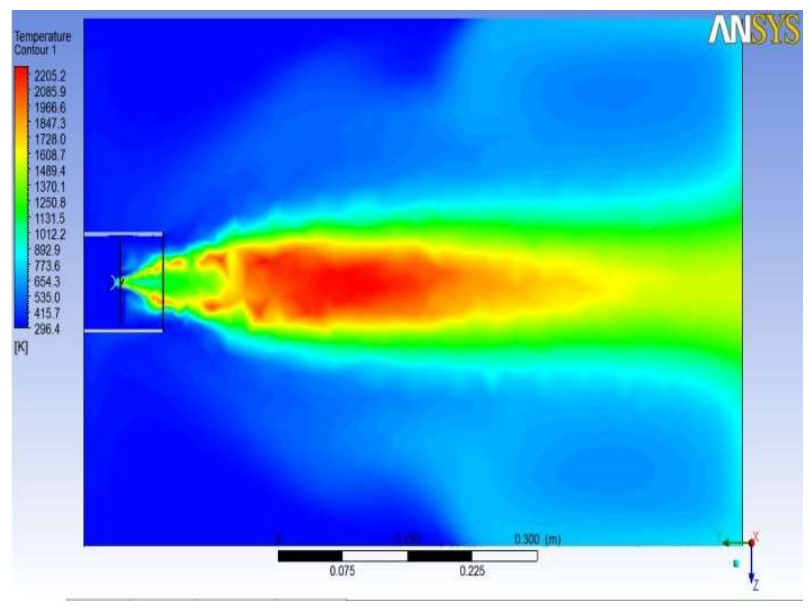

b)

Fig.10. The flame heat range a) for the mixture with a $30 \%$ concentration of bovine animal fat b) for the mixture with a 30 $\%$ concentration of swine animal fat

The reverse flow characteristic of the swirling was not noticed due to the presence of the initial flame control tube. Combustion research comprised and determined the combustion gas emissions at evacuation to the chimney, the measurements being made with the MAXYLIZER NG. Excessive air and pollutant emissions were monitored. A good burning, no pulsation of the flame and no particle emission, was achieved with an excess of air, ranging between 1.74 and 3.11. As shown in the figure 11 and figure 12, the combustion gas emissions do not depend of the fat mixing in the tested range. 


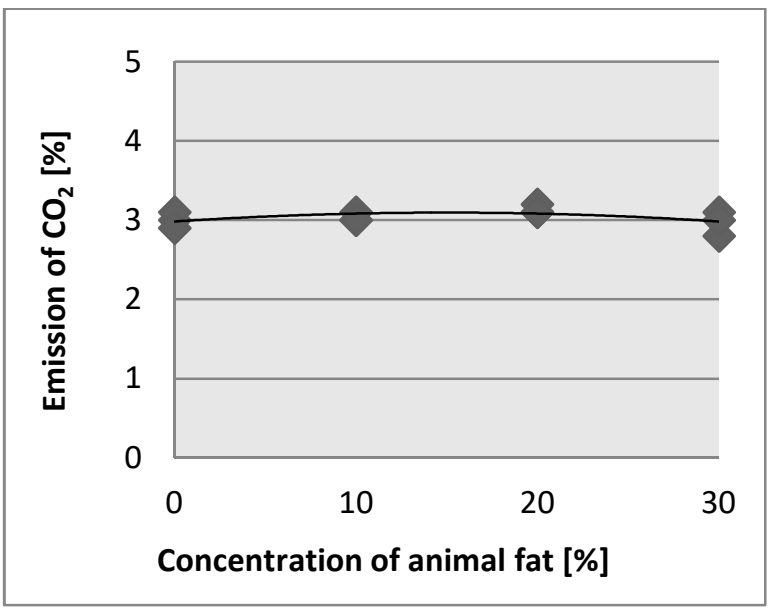

Fig.11. The variation of the emission of $\mathrm{CO}_{2}$ with the concentration of bovine animal fat

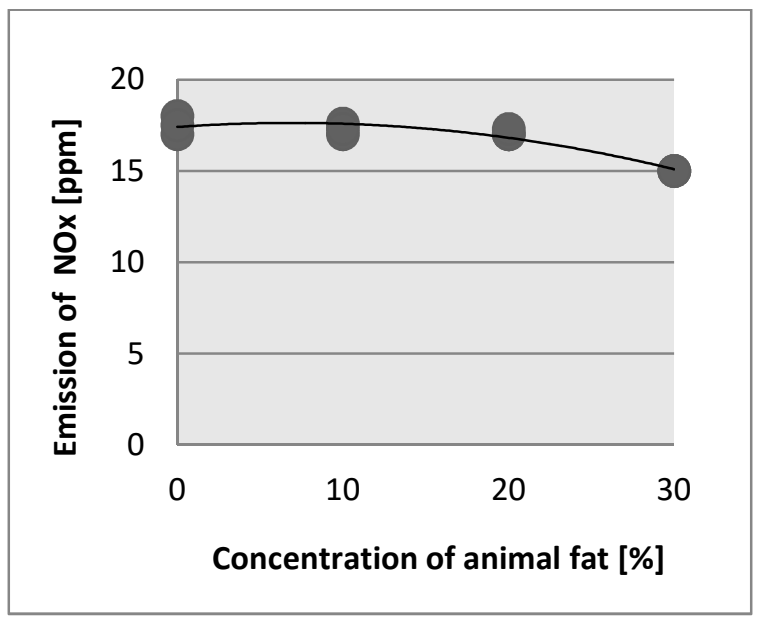

Fig.12. The variation of the emission of $\mathrm{NO}_{\mathrm{x}}$ with the concentration of bovine animal fat

The set of research methods consisting of the analytical study, experimental data and numerical simulation, confirms through the data convergence, the viability of the possibilities of burning animal fat mixed with liquid hydrocarbons. Regarding air pollution, a special attention was given to $\mathrm{NO}_{\mathrm{x}}$ emissions; this emission was measured in exhaust gases to the chimney. The measurements indicated very low values for nitrogen oxides, even observing a tendency to decrease when increasing the percentage of animal fat, bovine or swine - this tendency can be observed in figure 12 .

\section{Conclusion}

Many researches on the combustion of mixed animal fats with liquid hydrocarbons have shown total applicability in the use of industrial burners with mechanical spraying; these are equipped with spray pumps with pressures above 14 bar and also with heating the mixture in two steps to a temperature of $75{ }^{\circ} \mathrm{C}$. The data obtained by modelling and numerical simulation confirmed and completed the data obtained by analytical studies and experimental measurements. The experiments with $40 \%$ mixture animal fat in liquid hydrocarbons showed a pulsating flame as in figure 13 for a spray pressure increased to 18 bar.

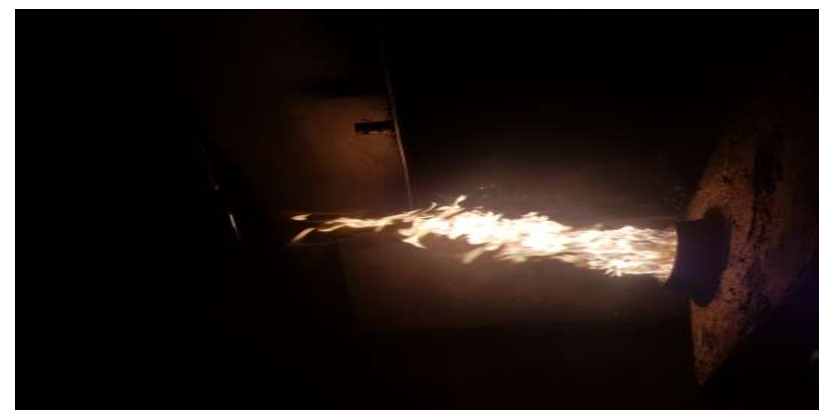

Fig.13. The aspect of the flame for $40 \%$ mixture animal fat with liquid hydrocarbons

The research has not continued on other types of burners, with higher spray pressures, because the obtained flame already indicates an incompatibility. The results obtained imposed the maximum limit of mixture with animal fat up to $30 \%$. Pollution has not increased by mixing liquid hydrocarbons with animal fat.

\section{Acknowledgment}

This work was supported by a grant from the Romanian Ministry of Research and Innovation, CCCDI-UEFISCDI, project number PN-III-P1-1.2-PCCDI-2017-0404/31PCCD/2018,within PNCDI.

\section{References}

[1] D.A. Bondrea, G. Lazaroiu, Analysis and simulation by ansys cfx of the aerodynamics flame for burning animal fats with liquid hydrocarbons, UPB Scientific Bulletin, Series D: Mechanical Engineering, BDI, 80, Issue 4, Pages 103 116, (2018).

[2] Environmental, Health, and Safety (EHS) Guidelines for Tanning and Leather Finishing (2010). 
[3] A. İșler, S. Sundu, M. Tüter, F. Karaosmanoğlu, Transesterification Reaction Of The Fat Originated From Solid Waste Of The Leather Industry, Waste Management 30 (2010) pages 2631-2635, Elsevier.

[4] M.E. Mavrodin., G. Lăzăroiu, Experimental research on combustion of biogas obtained through anaerobic fermentation of tanneries wastes, UPB Scientific Bulletin, Series B: chemistry and materials science, 80, Issue 3 Pages: 105-116, (2018).

[5] E. Onem, G. Gulumser, M. Renner, O. Yesil-Celiktas, High pressure vegetable tanning of sheepskins using supercritical carbon dioxide, The Journal of Supercritical Fluids, 104, Pages: 259-264, b (2015).

[6] G. Lazaroiu, C. Pana, L. Mihaescu, A. Cernat, N. Negurescu, R. Mocanu, G. Negreanu, Solutions for energy recovery of animal waste from leather industry, Energy Convers. Manag., 149, Pages: 1085-1095 (2017).

[7] G. Lazaroiu, E. Pop, G. Negreanu., I. Pisa, L. Mihaescu, A. Bondrea, V. Berbece, Biomass combustion with hydrogen injection for energy applications, Energy, 127, Pages: 351-357 (2017).

[8] L. Mihaescu., G. Lazaroiu, G.P. Negreanu, I. Pisa, Influence of the characteristics of biogas generated in the leather industry on combustion quality, Therm.sci., 22, Pages: S1349-S1357, Supplement: 5 (2018).

[9] D.A. Bondrea, G. Lazaroiu, R. Mocanu, A.N. Stan, L. Balanescu, L. Mihaescu, V. Berbece, The energy method to protect the environment form waste in the leather industry, $8^{\text {th }}$ International Conference On Energy And Environment (CIEM), Pages:105-109, Energy \& Fuels; Engineering, Book Series: International Conference on Energy and Environment (2017).

[10] G. Lazaroiu, R.C. Moacanu, A.D. Bondrea, E. M. Mavrodin, L. Balanescu, Use of animal fat waste as a bio-fuel, $17^{\text {th }}$ International Multidisciplinary Scientific GeoConference SGEM 2017, 17, Issue 42, Pages 675-682 (2017), Section Renewable Energy Sources and Clean Technologies, Bulgaria, Albena.

[11] K.E. Lorber, Waste Management and Treatment of Residues in the Leather-Tanning Industry -University of Leoben, Austria, 2009, Middle Pomeranian Scies. Society. of the Environ.t Protection, Pages: 8-28.

[12] L. Mihăescu, G. Lăzăroiu, I. Pîşă, E. Pop, G. Negreanu, V. Berbece, A. Bondrea, Analysis Of The Possibilities Of Combustion Of Animal Fat Mixed With Liquid Hydrocarbons In Boilers With Small Furnaces, ${ }^{\text {th }}$ International Conference on Thermal Equipment, Renewable Energy and Rural Development TE-RE-RD (2017), Proceeding, Romania, pages 83-86 (2017).

[13] L. Mihăescu „Arzătoare pentru hidrocarburi cu $\mathrm{NO}_{\mathrm{x}}$ scăzut”(Burners for hydrocarbons with low $\mathrm{NO}_{\mathrm{x}}$ ), Ed. Printech, Bucureşti 2004, ISBN 973-718-039-9.

[14] J. Kanagaraj, T. Senthilvelan, R.C. Panda, S. Kavitha, Eco-Friendly Waste Management Strategies For Greener Environment Towards Sustainable Development In Leather Industry: A Comprehensive Review, Jour. of Clean. Prod. 89 (2015) Elsevier, pages 1-17, (2015).

[15] G. Lăzăroiu, L. Mihăescu, I. Pîşă, E. Pop, C.R. Mocanu, Animal Fats Mixed With Liquid Hydrocarbons Combustion Efficiency, Proceedings of University of Ruse, Bulgaria, 55, pages 12-16 (2016).

[16] G. Lăzăroiu, L. Mihăescu, G. Negreanu, C. Pana, I. Pisa, A. Cernat, D.A. Ciupageanu, Experimental investigations of innovative biomass energy harnessing solutions, Energies, 11, Issue:12, (2018). 